УДК 330.341 .1

JEL Classification: O33

\title{
НАУКОВІ ШКОЛИ ЯК СКЛАДОВА ЧАСТИНА ІННОВАЦІЙНОГО СЕРЕДОВИЩА
}

Блага В.В., канд. екон. наук, доцент

Харківський національний автомобільно-дорожній університет

Благой В.В., канд. екон. наук, доцент

Харківський національний університет будівництва та архітектури

Хорошилова І.О., канд. екон. наук, доцент

Харківський національний автомобільно-дорожній університет

Постановка проблеми. Рівень освіти залежить від рівня економічного розвитку країни, причому для розвинених країн критично важливим для зростання $\epsilon$ розвиток вищої освіти. Реформування освітньої галузі - це відповідь на суспільний запит, адже саме освіта забезпечує якість людського капіталу, який $є$ основою економічного розвитку країни. Освіта дає додаткові непрямі вигоди, стимулюючи інвестиції в фізичний капітал, власний технологічний розвиток країни і адаптацію розроблених в інших країнах технологій. Перспективи науки завжди визначалися перспективами провідних наукових шкіл. Всі галузі світової науки досягли видатних висот завдяки науковим школам, будь-які наукові проблеми вимагають об'єднання зусиль вчених, створення колективів вчених. У цих умовах надмірно зростає значення наукових шкіл для розвитку національної економіки. Утворення наукових шкіл - це давня вітчизняна традиція, яка виходить 3 глибокого розуміння державної корисності.

Аналіз останніх наукових досліджень і публікацій. Проблеми освітніх і педагогічних інновацій, інноваційного розвитку освітніх систем та інноваційних процесів висвітлені у роботах I. Беха [1], Н. Бібік [2], Л. Ващенко [3], Л. Даниленко [4], Д. Пузікова [5], Г. Щекатунової [6] та ін.

Наука, за визначенням І. Беха [1] та Н. Бібік [2], є специфічною галуззю людської діяльності, відрізняється особливими цілями, методами їх досягнення, сукупністю знань, які об'єднують різні концепції, теорії, категоріальний апарат, також це соціальний інститут, який включає окремих вчених та їх формальні і неформальні об'єднання, організації, тощо.

На думку Л. Ващенко [3] та Л. Даниленко [4], важливим поняттям в системі наукового потенціалу країни $\epsilon$ наукове співтовариство, яке фактично означає одну із структурних одиниць науки. В цьому контексті можна виділити три групи наукових співтовариств: академічна наука, яка в умовах централізованої системи господарювання забезпечувала високий розвиток практично всіх фундаментальних напрямків; галузева наука, яка перетворила країну в одну з супердержав та вузівська наука, яка готує кадри і вносить свій вклад в академічну та галузеву науку. 
Як зазначають Д. Пузікова [5] та Г. Щекатунова [6], перспективи науки завжди визначалися перспективами провідних наукових шкіл. Особливо це характерно для XXI століття, коли всі галузі світової науки досягли видатних висот, а будь-які наукові проблеми вимагають об'єднання зусиль вчених, створення колективів вчених. У цих умовах особливо зростає значення наукових шкіл.

Однак в наукових публікаціях, присвячених дослідженню інноваційного освітнього середовища, недостатньо уваги приділено науковим школам та їх впливу на інноваційне середовища.

Невирішені складові загальної проблеми. Під впливом наукових шкіл виникають не тільки прямі, але і непрямі (зовнішні) ефекти (або екстерналії освіти), так як вигоди від одержуваної в індивідуальному порядку освіти можуть переходити до інших людей: до промисловості, до міста, до регіону та до країни в цілому. Виникає соціальна віддача освіти на макрорівні, відмінна від приватної, існування i значні масштаби якої дають економічне обгрунтування для громадської підтримки освіти. Чим більше соціальна віддача освіти в порівнянні з приватною, тим ефективнішими $є$ суспільні витрати на освіту. У «новій» економіці спеціально виділяють ендогенні детермінанти зростання, які визначаються всередині моделі. Тому виникає необхідність розроблення теоретичного фундаменту для розуміння того, як освіта може впливати на економічне зростання.

Формулювання цілей статті. Дослідити вплив наукових шкіл, що надають знання фундаментального характеру, на інноваційний розвиток будьякої галузі господарства та визначити їх місце в інноваційному середовищі 3 точки зору національних інтересів.

Виклад основного матеріалу дослідження. По-перше, людський капітал прямо включається як фактор витрат в виробничу функцію, причому в цьому випадку людському капіталу надається можливість мати екстернальні ефекти, так як він виключається 3 припущення про постійну віддачу від масштабу виробництва. По-друге, фактори, які ведуть до ендогенного зростання (особливо технологічні зміни), прямо пов'язуються 3 запасом людського капіталу в країні (в регіоні або місті). Такий зв'язок цілком природно припустити, так як людський капітал або прямо створюе нові знання i технології, або тому, що він $є$ ключовим компонентом витрат в дослідному секторі, який генерує нові знання і технології.

Рішення задач створення в країні інноваційної економіки потребує суттєвого зростання інвестицій в людський капітал, в першу чергу збільшення державних витрат на освіту як мінімум в два-три рази в найближчі роки. У проєкті Державного бюджету України на 2021 рік закладено збільшення видатків на освіту на 34 млрд гривень. Загальний бюджет освіти (без місцевих) складає 173,8 млрд гривень [7]. Видатки на підготовку кадрів у закладах вищої освіти зростуть на третину, до 21,9 млрд, а у коледжах і технікумах - на 25\%, до 4,9 млрд. Це помітне зростання, однак навіть близько не достатне для того, аби реалізувати постанову №822 «Про оплату праці педагогічних та науково- 
педагогічних працівників» [8]. Ця постанова описує перехід до обсягів оплати праці, передбачених законом «Про освіту», до 2023 року, і передбачає зростання зарплат освітян у 2-2,5 рази. Зростання, передбачене проєктом бюджету, навіть якщо знайдуть гроші на його реалізацію, означатиме «підтягування» найменших зарплат у сфері освіти до розміру мінімальної, а в середньому зарплати у сфері освіти просто трохи наблизяться до середньої по країні (бо зараз вони нижчі) [9].

Ключовим завданням державної політики має бути становлення і всіляка допомога в розвитку комплексу науки, освіти, інновацій в країні. Створення сприятливого інноваційного клімату в країні та можливість розвитку регіонів за базовими критеріями. До них доцільно віднести: розвинену систему вищої освіти, здатну задовольнити потреби регіону в висококваліфікованій робочій силі; систему регіональної науки, яка сприяє створенню та розвитку інноваційних ініціатив; інноваційну спрямованість державної влади, що включає комплекс заходів щодо організації інноваційної інфраструктури регіону; участь в експертизі запропонованих інноваційних проєктів, тощо.

Поряд 3 тим, навряд чи можна повністю погодитися 3 думкою, що саме освітянська наука повинна бути безпосереднім виробником нового продукту ринку або нового практично використовуваного технологічного процесу. Про це свідчить і міжнародний досвід. У розвинених країнах світу нові техніки і технології $\epsilon$ в переважній більшості результатом розробок найбільших транснаціональних корпорацій на власній дослідній базі з відповідним обсягом фінансування саме прикладних науково-технічних досліджень [10]. Однак розвинена система освіти і науки є саме тим «інноваційним середовищем», без якого неможливе виробництво таких нових знань, які безпосередньо комерціалізуються i тим самим забезпечують не тільки конкурентоспроможність окремих корпорацій, але й є двигуном конкуренції між країнами. При цьому основною складовою частиною цього інноваційного середовища повинні бути наукові школи, здатні виробляти, зберігати i передавати знання в першу чергу фундаментального характеру.

Наукова школа - це об'єднання дослідників, інтегрованих навколо вченого генератора ідей, який володіє особливими дослідними i, що також важливо, людськими якостями. Навколо такого вченого об'єднується група соратників і учнів, які поділяють його наукові ідеї і загальні теоретичні принципи, методологію дослідження. Важливою функцією подібної школи $\epsilon$ турбота про наукову зміну, про підготовку кандидатів і докторів наук. Вченийкерівник і його колеги прагнуть сформувати з числа дослідників (студентів, аспірантів, докторантів) наукових, а багато в чому і світоглядних однодумців. Процес формування наукових шкіл видатних учених досить довгий i трудомісткий. Вирішення цього завдання в умовах вищого навчального закладу полегшується тим, що науковий колектив одночасно виконує освітні та наукові функції. Творча атмосфера, наявність талановитих учнів 3 аспірантів i студентів, навчально-допоміжної та наукової бази допомагають вченому досягати істотних результатів в науці. Результатом навчання в науковій школі $\epsilon$ 
формування самостійного вченого 3 виявленою власною професійною та особистісною позицією. Для розвитку школи учень проводить дослідження у обраній сфері, результатом якого $є$ його внесок у інноваційний розвиток відповідної галузі господарства. Запропоновані результати функціонування наукової школи автоматично не випливають з системи знань вчителя, це власне і забезпечує спадкоємність ідей і діяльності у науці.

Висновки 3 проведеного дослідження. В якості висновків слід підкреслити, що особливість знань фундаментального характеру, що надають наукові школи, полягає в тому, що вони можуть дати потужний інноваційний поштовх розвитку будь-якої галузі господарства, і водночас, ймовірно, ніколи не будуть залучені в комерційний оборот, в технологічні цикли. Однак навіть у цьому випадку це не означає, що вони $\epsilon$ малокорисними 3 точки зору національних інтересів. При всій опосередкованості впливу вони зумовлюють можливості майбутнього еволюційного або революційного розвитку техніки i технологій в країні, а також сучасні можливості прикладного сектора у виробництві і сприйнятті нових технік і технологій. Саме сукупне знання суспільства, що кристалізується в науково-викладацькому середовищі, $\epsilon$ основою виробництва конкурентоспроможної продукції i благополуччя суспільства в цілому. Так, абсолютно неможливо передбачити безпосередній економічний ефект від витрат на систему науки і освіти, неможливо навіть припустити кількість інновацій, яка зародиться саме завдяки функціонуванню системи.

\section{Перелік посилань}

1. Бех I. Інноваційна виховна технологія: сутнісні положення та шляхи реалізації. Естетика і етика педагогічної дії. 2013. Вип. 5. С. 156-165.

2. Бібік Н. М. Переваги i ризики запровадження компетентнісного підходу в шкільній освіті. Украӥнський педагогічний журнал. 2015. № 1. С. 47-58.

3. Ващенко Л. М. Проблеми наукового аналізу інноваційного розвитку загальної середньої освіти. Педагогічна освіта: теорія і практика. Психологія. Педагогіка. 2017. № 28. С. 4-11.

4. Даниленко Л. І. Педагогічні умови формування готовності вчителя у післядипломній освіті до застосування інноваційних технологій інтерактивного навчання. Наукові записки Вінницького державного педагогічного університету імені Михайла Коцьюбинського. Серія : Педагогіка $і$ психологія. 2015. № 44. C. 123-127.

5. Пузіков Д. О. Теоретична модель прогнозування розвитку загальної середньої освіти. Украӥнський педагогічний журнал. 2017. № 4. С. 128-137.

6. Щекатунова Г. Д., Тесленко В. В., Цимбалару А. Д., Гораш К. В., Пузіков Д. О., Варава В. Ю., Волченкова Г. М. Організаційно-педагогічні засади інноваційного розвитку загальноосвітніх навчальних закладів : монографія. К. : Пед. думка, 2013. 264 с.

7. Фінансування освіти збільшиться на 34 мільярди гривень - проєкт бюджету на 2021 рік: сайт URL : https://mon.gov.ua/ua/news/finansuvannya-osviti- 
zbilshitsya-na-34-milyardi-griven-proyekt-byudzhetu-na-2021-rik (дата звернення 12.04.21).

8. Про оплату праці педагогічних, науково-педагогічних та наукових працівників закладів i установ освіти i науки: сайт URL : https://zakon.rada.gov.ua/laws/show/822-2019-\%D0\%BF\#Text (дата звернення 12.04.21).

9. Бюджет освіти 2021: зарплати вчителів, фінансування модернізації шкіл та боротьба 3 COVID-19: сайт URL : https://ife.pravda.com.ua/columns/2020/09/15/242342/ (дата звернення 12.04.21).

10. Освіта в Україні: виклики та перспективи. Інформаційноаналітичнй збірник: сайт URL

https://mon.gov.ua/storage/app/media/zagalna\%20serednya/serpneva-

konferencia/2020/metod-zbirka-osvita-ta-covid-2020.pdf (дата звернення 12.04.21).

\section{References}

1. Bekh, I. (2013), Innovative educational technology: essential provisions and ways of realization [Innovatsiina vykhovna tekhnolohiia: sutnisni polozhennia ta shliakhy realizatsii], Aesthetics and ethics of pedagogical action, Vip. 5, P. 156-165.

2. Bibik, N. M. (2015), Advantages and risks of introducing a competencybased approach in school education [Perevahy i ryzyky zaprovadzhennia kompetentnisnoho pidkhodu v shkilnii osviti], Ukrainian pedagogical journal, No 1, P. 47-58.

3. Vashchenko, L. M. (2017), Problems of scientific analysis of innovative development of general secondary education [Problemy naukovoho analizu innovatsiinoho rozvytku zahalnoi serednoi osvity], Pedagogical education: theory and practice. Psychology. Pedagogy, No 28, P. 4-11.

4. Danylenko, L. I. (2015), Pedagogical conditions for the formation of teacher readiness in postgraduate education for the use of innovative technologies of interactive learning [Pedahohichni umovy formuvannia hotovnosti vchytelia $\mathrm{u}$ pisliadyplomnii osviti do zastosuvannia innovatsiinykh tekhnolohii interaktyvnoho navchannia], Scientific notes of Vinnytsia State Pedagogical University named after Mykhailo Kotsyubynsky. Series: Pedagogy and Psychology, No 4, P. 128-137.

5. Puzikov, D. O. (2017), Theoretical model for predicting the development of general secondary education [Teoretychna model prohnozuvannia rozvytku zahalnoi serednoi osvity], Ukrainian pedagogical journal, No 44, P. 123-127.

6. Shchekatunova, H. D., Teslenko, V. V., Tsymbalaru, A. D., Horash, K. V., Puzikov, D. O., Varava, V. Yu., Volchenkova, H. M. (2013), Organizational and pedagogical principles of innovative development of secondary schools [Orhanizatsiino-pedahohichni zasady innovatsiinoho rozvytku zahalnoosvitnikh navchalnykh zakladiv : monohrafiia], monograph, K.: Ped. opinion, 264 p.

7. Funding for education will increase by 34 billion hryvnias - the draft budget for 2021 [Finansuvannia osvity zbilshytsia na 34 miliardy hryven - proiekt biudzhetu na 2021 rik], available at: https://mon.gov.ua/ua/news/finansuvannya-osvitizbilshitsya-na-34-milyardi-griven-proyekt-byudzhetu-na-2021-rik (last accessed 12.04.21). 
8. About payment of work of pedagogical, scientific-pedagogical and scientific workers of establishments and establishments of education and science [Pro oplatu pratsi pedahohichnykh, naukovo-pedahohichnykh ta naukovykh pratsivnykiv zakladiv i ustanov osvity i nauky], available at: https://zakon.rada.gov.ua/laws/show/822-2019-\%D0\%BF\#Text (last accessed 12.04.21).

9. Education budget 2021: teachers' salaries, funding for school modernization and the fight against COVID-19 [Biudzhet osvity 2021: zarplaty vchyteliv, finansuvannia modernizatsii shkil ta borotba $\mathrm{z}$ COVID-19], available at: https://life.pravda.com.ua/columns/2020/09/15/242342/ (last accessed 12.04.21).

10. Education in Ukraine: challenges and prospects. Information-analytical collection [Osvita v Ukraini: vyklyky ta perspektyvy. Informatsiino-analitychnyi zbirnyk], available at: https://mon.gov.ua/storage/app/media/zagalna\%20serednya/serpnevakonferencia/2020/metod-zbirka-osvita-ta-covid-2020.pdf (last accessed 12.04.21).

\section{РЕФЕРАТИ РЕФЕРАТЫ ABSTRACTS}

\section{УДК 330.341.1; JEL Classification: 033}

БЛага В.В., Благой В.В., Хорошилова І.О. НАУКОВІ ШКОЛИ ЯК СКЛАДОВА ЧАСТИНА ІННОВАЦЙНОГО СЕРЕДОВИЩА

Mema: дослідити вплив наукових шкіл, що надають знання фундаментального характеру, на інноваційний розвиток будь-якої галузі господарства та визначити їх місце в інноваційному середовищі з точки зору національних інтересів. Методика дослідження: аналіз значення науки як специфічної галузі людської діяльності та оцінка місця наукових шкіл в інноваційному середовище країни - для обгрунтування актуальності теми, мети за завдань дослідження; методи системного аналізу - для обгрунтування існуючого опосередкованого впливу наукових шкіл на майбутній еволюційній або революційній розвиток техніки і технологій в країні. Результати дослідження: визначено, що саме освітянська наука не повинна бути безпосереднім виробником нового продукту ринку або нового практично використовуваного технологічного процесу. Саме сукупне знання суспільства, що кристалізується в науково-викладацькому середовищі, $\epsilon$ основою виробництва конкурентоспроможної продукції і благополуччя суспільства в цілому. Так, абсолютно неможливо передбачити безпосередній економічний ефект від витрат на систему науки і освіти, неможливо навіть припустити кількість інновацій, яка зародиться саме завдяки функціонуванню системи. Наукова новизна: дістали подальшого розвитку функціональні особливості наукових шкіл, за рахунок включення опосередкованого впливу на майбутній еволюційній або революційній розвиток техніки і технологій в країні, що надає сучасні можливості прикладному сектору у виробництві і сприйняття нових технік і технологій. Практична значущість: визначено та обгрунтовано, що розвинена система освіти і науки є саме тим «інноваційним середовищем», без 
якого неможливе виробництво таких нових знань, які безпосередньо комерціалізуються i тим самим забезпечують не тільки конкурентоспроможність окремих корпорацій, але й є двигуном конкуренції між країнами. При цьому основною складовою частиною цього інноваційного середовища повинні бути наукові школи, здатні виробляти, зберігати i передавати знання в першу чергу фундаментального характеру.

Ключові слова: наукові школи; інноваційне середовище; фундаментальний характер; національні інтереси.

\section{УДК 330.341.1; JEL Classification: 033}

\section{Благая В.В., Благой В.В., Хорошилова И.А. НАУЧНЫЕ ШКОЛЫ КАК СОСТАВЛЯЮЩАЯ ЧАСТЬ ИННОВАЦИОННОЙ СРЕДЫ}

Цель: исследовать влияние научных школ, предоставляющих знания фундаментального характера, на инновационное развитие любой отрасли хозяйства и определить их место в инновационной среде с точки зрения национальных интересов. Методика исследования: анализ значения науки как специфической отрасли человеческой деятельности и оценка места научных школ в инновационной среде страны - для обоснования актуальности темы, цели и задач исследования; методы системного анализа - для обоснования существующего опосредованного влияния научных школ на будущее эволюционное или революционное развитие техники и технологий в стране. Результаты исследования: определено, что именно образовательная наука не должна быть непосредственным производителем нового продукта на рынок или нового практически используемого технологического процесса. Именно совокупное знание общества кристаллизуется в научно-преподавательской среде, что является основой производства конкурентоспособной продукции и благополучия общества в целом. Так, совершенно невозможно предсказать непосредственный экономический эффект от затрат на систему науки и образования, невозможно даже предположить количество инноваций, которые зародятся именно благодаря функционированию системы. Научная новизна: получили дальнейшее развитие функциональные особенности научных школ, за счет включения опосредованного влияния на будущее эволюционное или революционное развитие техники и технологий в стране, что предоставляет современные возможности прикладному сектору в производстве и восприятие новых техник и технологий. Практическая значимость: определено и обосновано, что развитая система образования и науки является именно той «инновационной средой», без которой невозможно производство новых знаний, которые непосредственно коммерциализируются и тем самым обеспечивают не только конкурентоспособность отдельных компаний, но и являются двигателем конкуренции между странами. При этом основной составляющей частью этой инновационного среды должны быть научные школы, способные производить, хранить и передавать знания в первую очередь фундаментального характера.

Ключевые слова: научные школы; инновационная среда; фундаментальный характер; национальные интересы. 


\section{UDC 330.341.1; JEL Classification: O33}

Blaga V.V., Blagoy V.V., Khoroshilova I.A. SCIENTIFIC SCHOOLS AS AN INTEGRAL PART OF THE INNOVATION ENVIRONMENT

Purpose: to study the influence of scientific schools that provide knowledge of a fundamental nature on the innovative development of any branch of the economy and determine their place in the innovative environment from the point of view of national interests. Methodology of research: analysis of the importance of science as a specific field of human activity and assessment of the place of scientific schools in the innovative environment of the country - to justify the relevance of the topic, the purpose of the research; methods of system analysis to substantiate the existing indirect influence of scientific schools on the future evolutionary or revolutionary development of machinery and technology in the country. Findings: it is determined that it is educational science that should not be a direct manufacturer of a new product to the market or a new practically used technological process. It is the aggregate knowledge of society that crystallizes in the scientific and teaching environment, which is the basis for the production of competitive products and the well-being of society as a whole. Thus, it is absolutely impossible to predict the direct economic effect of the costs of the system of science and education, it is impossible even to predict the number of innovations that will arise precisely due to the functioning of the system. Originality: the functional features of scientific schools were further developed, due to the inclusion of an indirect influence on the future evolutionary or revolutionary development of technology and technology in the country, which provides modern opportunities for the applied sector in production and the perception of new techniques and technologies. Practical value: it was determined and substantiated that a developed system of education and science is precisely that "innovation environment", without which it is impossible to produce new knowledge that is directly commercialized and thereby ensure not only the competitiveness of individual companies, but also are the engine of competition between countries. At the same time, the main component of this innovative environment should be scientific schools capable of producing.

Key words: scientific schools; innovative environment; fundamental character; national interests. 


\section{Відомості про авторів / Сведения об авторах / About the Authors}

Блага Вікторія Вікторівна - кандидат економічних наук, доцент, Харківський національний автомобільно-дорожній університет, доцент кафедри економіки і підприємництва, м. Харків, Україна; e-mail: blagavikvik@meta.ua; ORCID: https://orcid.org/0000-0001-8386-0767. Моб. (050) 610-10-14.

Благая Виктория Викторовна - кандидат экономических наук, доцент, Харьковский национальный автомобильно-дорожный университет, доцент кафедры экономики и предпринимательства, г. Харьков, Украина.

Blaga Viktoriya - PhD in Economics, Associate Professor, Kharkiv National Automobile and Highway University, Associate Professor of Department of Economics and Entrepreneurship, Kharkiv, Ukraine.

Благой Віталій Валерійович - кандидат економічних наук, доцент, Харківський національний університет будівництва та архітектури, доцент кафедри економіки, м. Харків, Україна; e-mail: blagoyvitval@i.ua; ORCID: https://orcid.org/0000-0002-0702-561X. Моб. (050) 512-60-50.

Благой Виталий Валерьевич - кандидат экономических наук, доцент, Харьковский национальный университет строительства и архитектуры, доцент кафедры экономики, г. Харьков, Украина.

Blagoy Vitaly - PhD in Economics, Associate Professor, Kharkiv National University of Construction and Architecture, Associate Professor of Department of Economics, Kharkiv, Ukraine.

Хорошилова Ірина Олександрівна - кандидат економічних наук, Харківський національний автомобільно-дорожній університет, доцент кафедри обліку та оподаткування, м. Харків, Україна; e-mail: hia23@ukr.net; ORCID: https://orcid.org/0000-00015343-5161. Моб. (050) 307-97-03.

Хорошилова Ирина Александровна - кандидат экономических наук, Харьковский национальный автомобильно-дорожный университет, доцент кафедры учета и налогообложенияй, г. Харьков, Украина.

Khoroshilova Irina - PhD in Economics, Kharkiv National Automobile and Highway University, Associate Professor of Department of Accounting and Taxation, Kharkiv, Ukraine. 